\title{
AN UNDERSTANDING ON THE FEASIBILITY OF AQUAPONICS IN INTENSIVE AQUACULTURE POND
}

\section{Partha Sarathi Das ${ }^{1}$, M. Mahfujul Haque ${ }^{1}$, M. Mehedi Alam $^{2 *}$, Shamima Akter ${ }^{3}$, and M. Ruhul Amin ${ }^{1}$}

${ }^{1}$ Department of Aquaculture, ${ }^{2}$ Department of Fisheries Technology, and ${ }^{3}$ Department of Fisheries Management, Faculty of Fisheries, Bangladesh Agricultural University, Mymensingh-2202, Bangladesh

*Corresponding author: M. Mehedi Alam, E-mail: imran01bau@yahoo.com

\section{ARTICLE INFO ABSTRACT}

Received

20.03.2015

Accepted

12.04.2015

Online

19.04.2015

Key words Aquaponics

Intensive aquaculture Water spinach

Stinging catfish

Carps pond
The study was conducted in a peri-urban village named, Panchpy under Gafargaon upazila of Mymensingh district with stinging catfish (Heteropneustes fossilis) and carps ponds to produce aquaponics vegetable kolmi (water spinach, Ipomoea aquatica) towards using waste substances of intensive stinging catfish ponds. Aquaponic plant (water spinach, Ipomoea aquatica) was grown in floating trays in the selected ponds. The water quality parameters including, temperature, $\mathrm{pH}$, dissolved oxygen, nitrite and ammonia were measured during study period.The level of ammonia was higher in catfish pond compared to carps pond water. Inversely, the dissolved oxygen content of catfish pond water was lower than that of carps pond. In the stinging catfish pond, the mean value ( \pm SE) of plant length, weight, number of branches and leaves were recorded at $27.67 \pm 1.76,62.67$ $\pm 2.03,13.00 \pm 1.15$ and $55.33 \pm 3.18$, respectively. The corresponding values 19.33 $\pm 1.45,46.67 \pm 1.86,9.33 \pm 1.45$ and $43.00 \pm 2.88$, respectively in carps pond, were significantly lower than that of catfish pond. Overall the percent weight gain of kolmi was higher in catfish pond. A positive correlation was found between the length and weight of kolmi produced in both catfish and carp ponds, however $\mathrm{R}^{2}$ value of that relationship was higher for catfish pond due to higher level of available waste nutrients in water. This indicates that the potential of aquaponics research and development in intensively feed catfish aquaculture ponds at the farmer level that can feed the growing population in both rural and urban areas of Bangladesh.

To cite this article: PS Das, MM Haque, MM Alam, S Akter and MR Amin. 2015. An understanding on the feasibility of aquaponics in intensive aquaculture pond. Res. Agric. Livest. Fish. 2 (1): 143-150. 


\section{INTRODUCTION}

The term aquaponics is a portmanteau of the terms aquaculture and hydroponic (Mohamad et al., 2013). Aquaponics has been recognized as a sustainable food production system that combines a traditional aquaculture (raising aquatic animals such as snails, fish, crayfish or prawns in tanks) with hydroponics (cultivating plants in water) in a symbiotic environment. In aquaculture, effluents accumulate in the water create pollution to the aquatic environment that in turn increases the toxicity to the fish (Rakocy et al., 2004). This kind of polluted water can be linked to the hydroponic system where the by-products from the aquaculture are filtered out by the plants as vital nutrients, after which the cleansed water is re-circulated back to the animals.

Aquaponics system consists of two main parts, with the aquaculture part for raising aquatic animals and the hydroponics part for growing plants. Aquatic effluents resulting from uneaten feed of raising animals like fish accumulates in water due to the closed system. The effluent-rich water becomes toxic to the aquatic animal in high concentrations but these effluents possess various nutrients which are essential for plant growth. Although consisting primarily of these two parts, aquaponics systems are usually grouped into several components or subsystems responsible for the effective removal of effluents, for adding bases to neutralize acids, or for maintaining dissolved oxygen in water (Rakocy et al., 2006). Typical components of indoor aquaponics systems are rearing tank, solids removal bio-filter, hydroponics subsystem and sump. Generally plants are grown in aquaponics systems, with their roots immersed in the nutrient-rich effluent water. This enables them to filter out the ammonia from the effluents which is toxic to fish. After the water has passed through the hydroponic subsystem, it becomes cleaned and oxygenated, and can return to the aquaculture vessels (Wilson and Brian, 2006).

Recent advances by researchers and growers alike have turned aquaponics into a working model of sustainable food production. The integration of fish and plants results in a polyculture that increases diversity and yields multiple products. Over the last three decades, Bangladesh has got tremendous development in the area of aquaculture (DoF, 2014). Aquaculture development as a whole in the country in combination with production technology, favorable socioeconomic condition and culture environment has already proven successful in terms of increasing productivity, improving profitability and maintaining sustainability (Toufique and Belton, 2014). However, the intensive aquaculture systems particularly Pangasius catfish (Pangasianodon hypophthalmus) aquaculture has got several problems such as sediment deposition in the pond bottom, water pollution, poor fish growth and production and local environmental degradation (Haque, 2009; Ali et al., 2011; Anka et al., 2013). Stinging catfish (Heteropneustes fossilis) aquaculture has been developing along with Pangasius with similar kind of problems. This kind of problems could be minimized integrating aquaculture with hydroponics (Tyson et al., 2011). Aquaponics is relatively a new practice of aquaculture in Bangladesh for which very little works have been carried out. In this context, this research initiative was taken at the farmer level with the objectives to determine water quality parameters of intensive stinging catfish ponds where aquaponics system was tested to have an understanding of production performance of an aquaponic plant, water spinach, Ipomoea aquatica, which is called kolmi in Bengali.

\section{MATERIALS AND METHODS}

\section{Location of the study area}

This study was conducted at Gafargaon upazila of Mymensingh district where intensive catfish aquaculture is growing rapidly (Ahmed, 2009). In 2012, Mymensingh district was ranked first for pond fish production in Bangladesh, producing 2,43,100 MT and contributing $18 \%$ to the total pond fish production (FRSS, 2011-12). The intensive catfish culture (such as Pangasius catfish, stinging catfish) has been developing in all the upazilas of Mymensingh district in different scales. The number of ponds in Gafargaon upazila was 10,259 in 2000 and which was 11,200 in 2014 indicating the steady growth of aquaculture farms in the study area (DoF, 2015). 


\section{Selection of the study site}

The experiment was conducted in the catfish and carps ponds of Panchpy village at Gafargaon upazila of Mymensingh district (Fig. 1). The study site was taken due to having available stinging catfish ponds which is the growing intensive production system of aquaculture and closed proximity of the location to the periurban community of Gafargaon upazila town having increasing demand of fish and vegetables regularly.

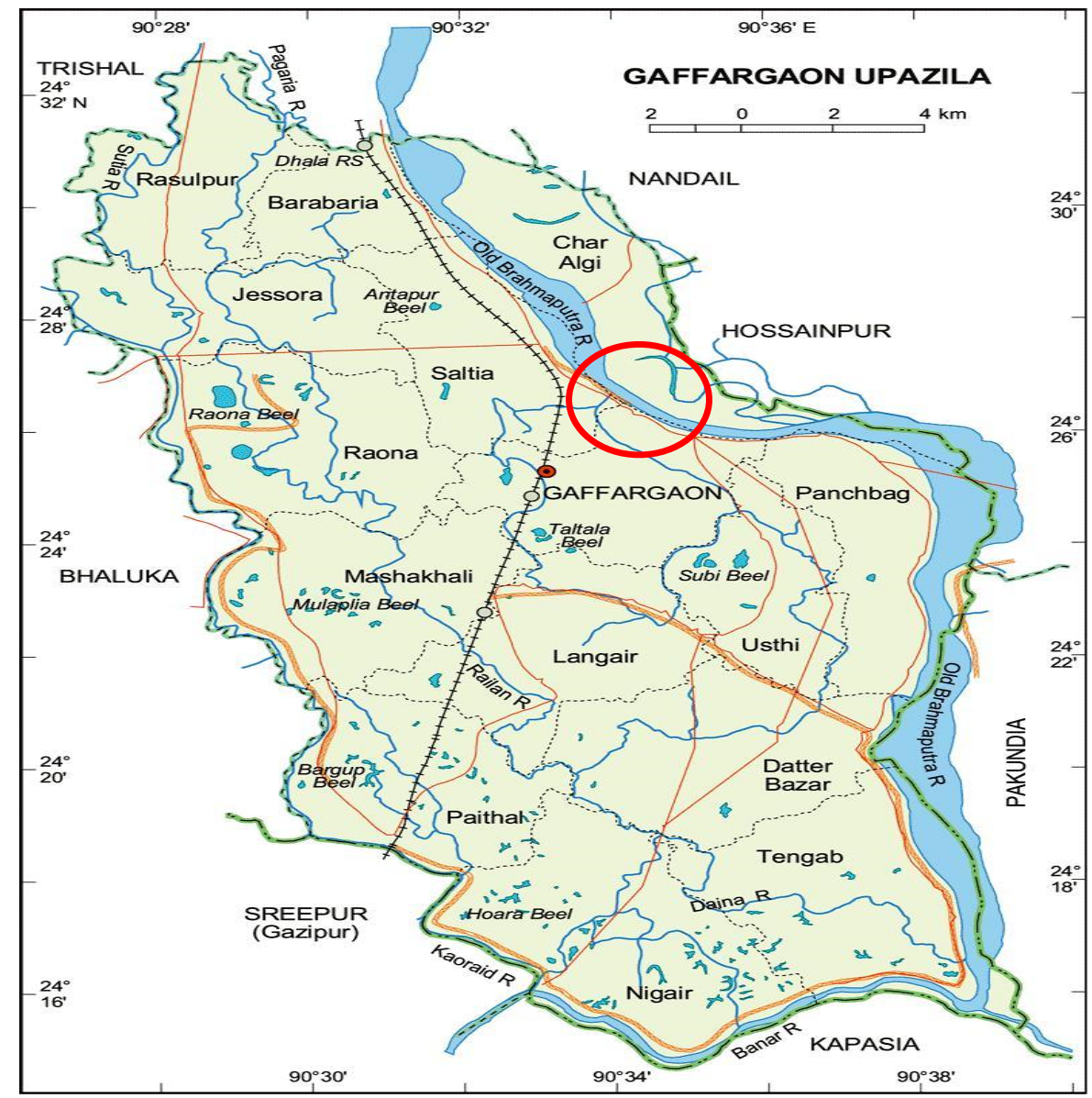

Figure 1. Map (source: http://www.banglapedia.org) of Gafargaon upazila showing the study site (encircled).

\section{Experimental design}

This experiment was carried out in two ponds, one for stinging catfish (locally called shing) culture and other one for carps polyculture. The culture characteristics of catfish and carps are summerized in the Table 1. The catfish pond was stocked with shing ( $H$. fossilis) and koi (Anabas testudineus) at the stocking density of $98,800 /$ ha by the farmers as per their common practices. On the other hand, carps culture was carried out at the stocking density of 12,350/ha as per their traditional practices (Table 1).

This experiment was desinged to assess aquaponics systems comparatively in catfish and carps pond following independent sample T-test, statistically. In each pond, 3 plastic trays each with the size of $0.12 \mathrm{~m}^{2}$ were set in catfish pond and similar sized 3 trays were set in carps pond. These two sets of trays were designated as two differenet treatments $\left(T_{1}\right.$ and $\left.T_{2}\right)$. Four plastic bottles were set with each tray for floating the trays on the pond surfcae. On the floor of each tray, a thick layer of pond sedimnet taking from the same pond was made. In each of the tray, 6 cuttings of kolmi were planted in both of the treatments. Before planting of the cuttings, the weight, number of branches, leaves etc. of an individual cutting were measured. At the end of this experiment, about one month later, the final length, weight, number of branches, leaves etc. of an individual plant were also measured. 
Table 1. Culture characteristics of catfish and carps in experimental ponds

\begin{tabular}{|c|c|c|}
\hline Attributes & Stinging catfish culture & Carps culture \\
\hline $\begin{array}{l}\text { Stocking density } \\
\text { Species combination }\end{array}$ & $\begin{array}{l}98800 \text { fingerling/ha } \\
\text { Stingning catfish (80\%), Climbing } \\
\text { perch }(20 \%)\end{array}$ & $\begin{array}{l}12350 \text { fingerling/ha } \\
\text { Rohu (35\%), Catla (20\%), Silver carp (10\%), } \\
\text { Mrigal (15\%), Common carp (20\%) etc. }\end{array}$ \\
\hline Culture period & 6-7 month & 6-10 month \\
\hline Feeding & Commercial feed & Supplemenraty feed (rice bran, wheat bran) \\
\hline Harvesting pattern & Harvest at the end & Partial harvesting (Using cast net) \\
\hline Production & $3458 \mathrm{~kg} / \mathrm{ha}$ & $3050 \mathrm{~kg} / \mathrm{ha}$ \\
\hline FCR & 2.2 & 0.9 \\
\hline Water exchange & $\begin{array}{l}\text { Only discharge of water during } \\
\text { monsoon }\end{array}$ & Only discharge of water during monsoon \\
\hline
\end{tabular}

\section{Study of water quality parameters}

To understand the enviromnetal condition of pond, the physico-chemical parameters of water were needed to be measured. The main parameters including temperature, $\mathrm{pH}$, dissolved oxygen, nitrate and ammonia were measured before starting the experiment. Water quality testing kits (Model: Sera test kit) were applied to test physico-chemical parameters of the ponds water. Initially the measuring vials were ringed well with pond water which was being tested. The collected water sample from the mid-layer of the pond was tested on the pond side following the instructions labelled on Sera test kit to determine the water quality parameters.

\section{Study of growth parameters of water spinach}

For determing the growth parameters, length, weight and number of leaves and branches were taken into consideration. The height of kolmi was measured from bottom to the tip of the plants by a centimeter scale. Accordingly, the weight of kolmi was measured by an electronic balance (Model: HKD-620AS-LED) in grams. The number of leaves and branches of kolmi was recorded manually based on eye observation. The percent gain of growth parameters of the aquaponic plan were measured using the following formula.

$$
\% \text { gain }=\frac{\text { Final stage }- \text { Initial stage }}{\text { Initial stage }} \times 100
$$

\section{Data processing and analysis}

The recorded data were entered into the spreadsheet in MS Excel 2010 and then summarized properly before ststistical anslysis. After entering the data, the descriptive statistical analyses were done by MS Excel. The inferential T-test was carried out using SPSS (Ststistical Package for Social Sciences) version 16.

\section{RESULTS AND DISCUSSION}

\section{Water quality parameters}

Aquaculture production depends on physical, chemical and biological qualities of pond water to a greater extent. The successful pond management requires an understanding of water quality. Intensification of pond makes the water quality undesirable with a number of water quality parameters. Pond water quality is largely defined by temperature, transparency, turbidity, water color, carbon dioxide, pH, alkalinity, hardness, unionized ammonia, nitrite, nitrate, primary productivity, biological oxygen demand and plankton population (Bhatnagar and Devi, 2013). The average mean values of tested water quality parameters such as temperature, $\mathrm{pH}$, dissolved oxygen, nitrate and ammonia of the experimental ponds are presented in Table 2. Apart from dissolved oxygen and ammonia, other water quality parameters were within the suitable range of aquaculture in Bangladesh. However, ammonia content in catfish pond water was significantly $(p<0.05)$ higher than that of carps pond water. The accepted level of ammonia should be under the range of 0.05 to $0.10 \mathrm{mg} / \mathrm{l}$ (Shoko et al., 2014) and above range it is toxic to the cultured fish (Francis-Floyd et al., 2009). Higher level of ammonia content was found associated with lower level of dissolved oxygen in the catfish pond water (Table 2). In this situation, aquaponics system tested in the catfish pond could be the solution to maintain acceptable level of water quality parameter. 
Table 2. Average (Mean \pm SE) values of water quality parameters between two treatments throughout the study period

\begin{tabular}{|lrr|}
\hline Water quality parameters & Catfish pond & Carps pond \\
\hline Temperature $\left({ }^{\circ} \mathrm{C}\right)$ & $28.00 \pm 0.00$ & $28.00 \pm 0.00$ \\
$\mathrm{pH}$ & $7.43 \pm 0.03$ & $7.73 \pm 0.03$ \\
Dissolved oxygen $(\mathrm{mg} / \mathrm{l})$ & $4.0 \pm 0.00$ & $6.0 \pm 0.00$ \\
Nitrite $(\mathrm{mg} / \mathrm{l})$ & 0.00 & 0.00 \\
Ammonia $(\mathrm{mg} / \mathrm{l})$ & $0.05 \pm 0.00$ & $0.02 \pm 0.00$ \\
\hline
\end{tabular}

\section{Growth and production of aquaponic plant}

The initial length of a cutting of kolmi both in stinging catfish and carps pond was $7.00 \mathrm{~cm}$ which was differred significantly $(p<0.05)$ between the catfish $(27.67 \pm 1.76 \mathrm{~cm})$ and carps $(19.33 \pm 1.45 \mathrm{~cm})$ pond after the end of trial (Table 3). Similarly, final weight of a cutting was singnificanly higher in catfish pond compared to carps pond. The number of branches per individual cutting during plantation was none, however, this was signifincatly higher in stinging catfish pond $(13.00 \pm 1.15)$ compared to carps pond $(9.33 \pm 1.45)$ after one month of trial (Table 3). As with branches, the number of leaves were higher in the trays palced in the catfish ponds than that of carps ponds. Accordingly total biomass $\left(\mathrm{kg} / \mathrm{m}^{2}\right)$ of water spinach was signifncaly higher in catfish pond compared to that of carps pond.

Overall, the growth performances of aquaponic plant were encouraging in stinging catfish ponds compared to carps ponds. This was due to the presence of nitrogenous waste available in the stinging catifsh ponds. According to Mizanur et al. (2004), intensive aquaculture ponds sediments has various fertilizing components such as nitrogen, phosphorous, sulphur etc. which are very useful for growth and production of aquaponic plants. Moreover, water spinach is an efficient plant having clustered roots that can absorb nutrients from the water very efficiently (Kibria and Haque, 2012).

Table 3. Mean value ( \pm SE) of growth parameters of water spinach in stinging catfish and carps pond

\begin{tabular}{|lrrrrrr|}
\hline Growth parameters & \multicolumn{3}{c}{ Catfish pond } & \multicolumn{2}{c|}{ Carp pond } & \% gain \\
\cline { 2 - 6 } & Initial & Final & \% gain & Initial & Final & \% \\
\hline Plant length $(\mathrm{cm})$ & 7 & $27.67 \pm 1.76$ & 295.29 & 7 & $19.33 \pm 1.45$ & 176.14 \\
Plant weight $(\mathrm{g})$ & 2 & $62.67 \pm 2.03$ & 3033.33 & 2 & $46.67 \pm 1.86$ & 2233.33 \\
No. of branches & 1 & $13.00 \pm 1.15$ & 1200.00 & 1 & $9.33 \pm 1.45$ & 833.00 \\
No. of leaves & 1 & $55.33 \pm 3.18$ & 5433.00 & 1 & $43.00 \pm 2.88$ & 4200.00 \\
Total biomass $\left(\mathrm{kg} / \mathrm{m}^{2}\right)$ & & $3.13 \pm 1.8$ & & & $2.33 \pm 1.3$ & \\
\hline
\end{tabular}

\section{Relative length and weight gain}

The percent length gain of the water spinach grown in the trays placed in catfish ponds was significantly $(p<0.05)$ higher than that of carps pond (Figure 2). Similarly, the percent weight gain of water spinach grown in the tray placed in stinging catfish pond was higher $(p<0.05)$ than carps pond. This was due to the fact that stinging catfish pond has the waste in the form of ammonia in water which has been used by water spinach as fertilizer (Turcios and Papenbrock, 2014).

\section{Relationship between plant growth parameters}

There was a positive relationship found between plant weight $(\mathrm{g})$ and length $(\mathrm{cm})$ produced in the trays of catfish pond (Figure 3). The increasing live weight of individual plant of water spinach was depended largely $\left(R^{2}=0.9276\right)$ on the increasing growth in length. The similar type of relationship was found for water spinach grown in the tray placed in carps pond (Figure 4), however, this relationship between weight and length was not as stronger as in catfish ponds. 


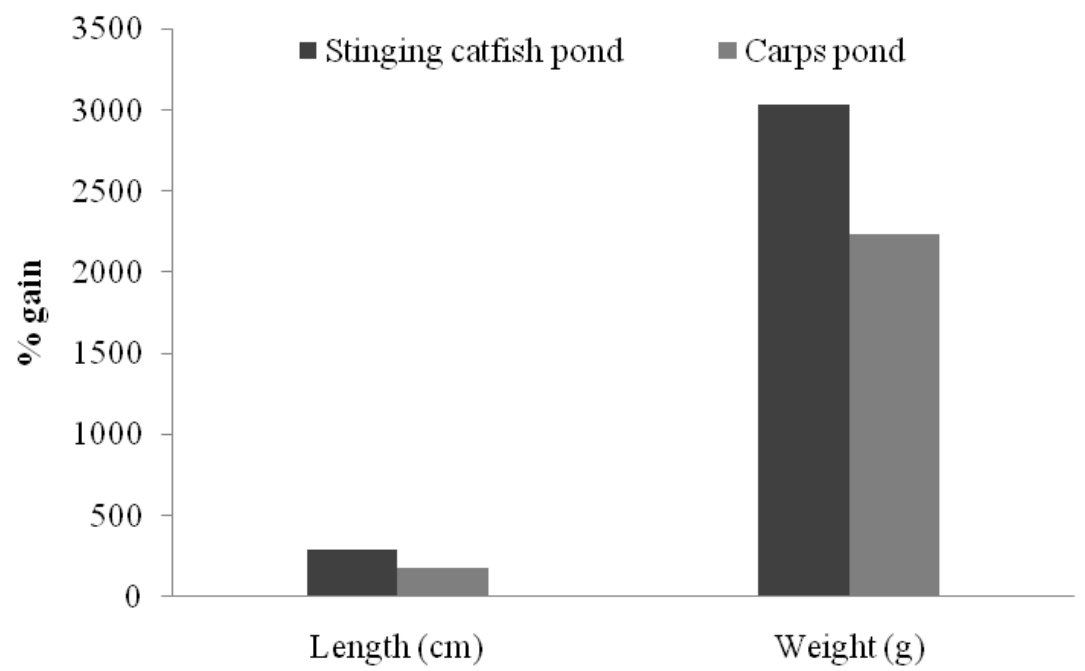

Figure 2. Comparative percent length and weight gain of live water spinach grown in the tray placed in stinging catfish and carps pond.

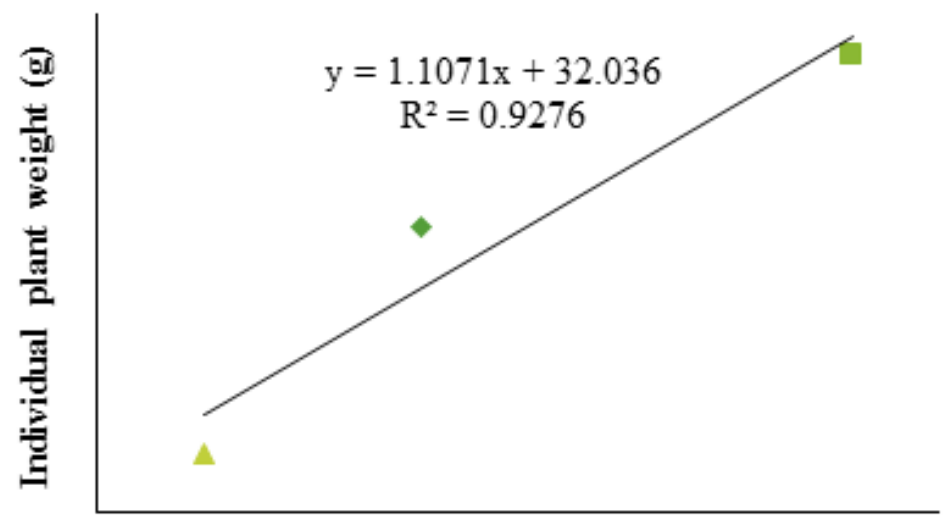

\section{Individual plant length (cm)}

Figure 3. Relationship between kolmi weight $(\mathrm{g})$ and length $(\mathrm{cm})$ in stinging catfish pond.

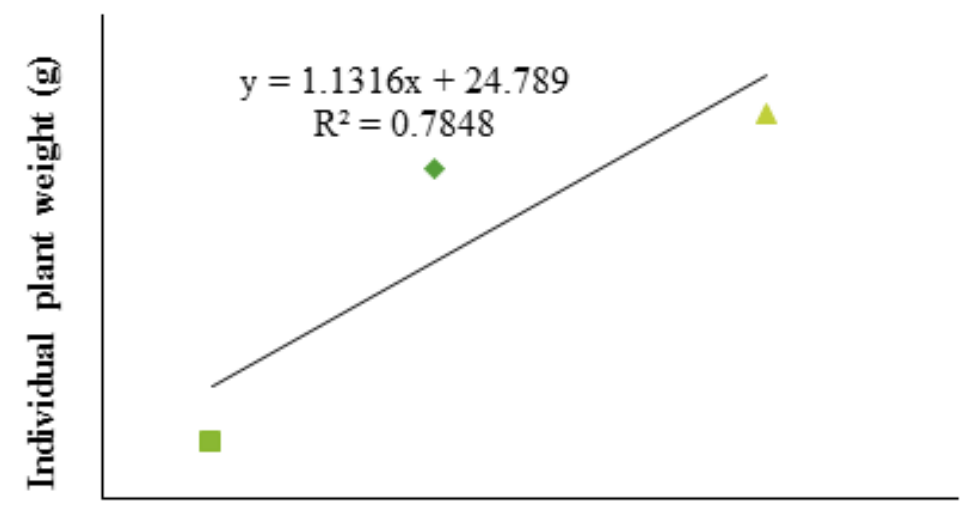

Individual plant length (cm)

Figure 4. Relationship between kolmi weight $(\mathrm{g})$ and plant length $(\mathrm{cm})$ in carps pond. 
According to DEPI (2002), the length-weight relationship of water spinach depends on the fertility of media from where nutrients are supplied. The plant's length-weight relationship is attributed to a variety and concentration of nutrients, of which nitrogen is the dominating factor. Waste water of stinging catfish ponds supplied various nitrogenous components of which ammonia has considerable fertilizing supports to the plant under floating condition on the pond surface (Kibria and Haque, 2012).

\section{CONCLUSION}

Aquaculture industry is now contributing to increasing demand of animal protein along with livelihoods of millions of people but full potential of aquaculture has not been realized yet and further development is required to keep up demand for nutrition from various sources. This study proved that floating aquaponics system could be developed in the intensive aquaculture ponds in Bangladesh to ensure production of nutrient rich fish and micro-nutrient rich vegetables in the balanced environmental condition of ponds. Further largescale research works need to be carried out to design and construct proper floating aquaponics system with appropriate ratio of pond area so that maximum waste materials could be minimized.

\section{REFERENCES}

1. Ahmed N, 2009. Revolution in small-scale freshwater rural aquaculture in Mymensingh, Bangladesh. World Aquaculture, 40: 31-35, 54.

2. Ali $\mathrm{H}$ and $\mathrm{MM}$ Haque, 2011. Impacts of Pangasius aquaculture on land use patterns in Mymensingh district of Bangladesh. Journal of the Bangladesh Agricultural University, 9: 169-178.

3. Anka IZ, MAR Faruk, MM Hasan and MAK Azad, 2013. Environmental issues of emerging pangas (Pangasianodon hypophthalmus) farming in Bangladesh. Progressive Agriculture, 24: 159 - 170.

4. Bhatnagar $A$ and $P$ Devi, 2013. Water quality guidelines for the management of pond fish culture. International Journal of Environmental Science, 3: 6.

5. DEPI, 2002. Water Spinach (Kangkong). Department of Environment and Primary Industries. Melbourne, Victoria, Australia.

6. DoF, 2014. Sankalan, Matsha Saptaho. Department of Fisheries (DoF), Ministry of Fisheries and Livestock, Dhaka, Bangladesh. pp.128.

7. DoF, 2015. Fisheries Statistics at a Glance, Gafargaon Upazila Office, Department of Fisheries, Ministry of Fisheries and Livestock, Bangladesh.

8. Francis-Floyd R, C Watson, D Petty and DB Pouder, 2009. Ammonia in aquatic systems (Univ. Florida, Dept. Fisheries Aquatic Sci., Florida Coop. Ext. Serv. FA-16), <http://edis.ifas.ufl.edu/FA031>. Date of Access 01 January, 2015.

9. FRSS, 2011-12. Fisheries statistical yearbook of Bangladesh 2011-2012. Department of Fisheries, Ministry of Fisheries and Livestock, Dhaka.

10. Haque MM, 2009. Assessment of Stakeholders' Perceptions on Pangasius Aquaculture Dialogue (PAD) Standards in two Pangasius Farming Villages in Bangladesh. Working paper of DelPHE Project, Faculty of Fisheries, Bangladesh Agricultural University, Mymensingh, Bangladesh.

11. Kibria ASM and MM Haque, 2012. Integrated Multi-Trophic Aquaculture (IMTA) Systems in Freshwater Ponds in Bangladesh: Initial Understanding. Department of Aquaculture, Bangladesh Agricultural University, Mymensingh, Bangladesh.

12. Mizanur R, A Yakupitiyage and SL Ranamukhaarachchi, 2004. Agricultural use of fish pond sediment for environmental amelioration. Thammasat International Journal of Science and Technology, 9(4):112.

13. Mohamad NR, ASAM Soh, A Salleh, NMZ Hashim, MZAA Aziz, N Sarimin, A Othman and ZA Ghani, 2013. Development of Aquaponic System using Solar Powered Control Pump. Journal of Electrical and Electronics Engineering, 8: 01-06. 
14. Rakocy JE, DS Bailey, RC Shultz and ES Thoman, 2004. Update on Tilapia and Vegetable Production in the UVI Aquaponic System. (PDF/251K). pp. 676-690. In: New Dimensions on Farmed Tilapia: Proceedings of the Sixth International Symposium on Tilapia in Aquaculture, Manila, Philippines.

15. Rakocy JE, MP Masser and TM Losordo, 2006. Recirculating Aquaculture Tank Production Systems: Aquaponics - Integrating Fish and Plant Culture. Southern Regional Aquaculture Center, SARC Publication No. 454.

16. Shoko AP, SM Limbu, HDJ Mrosso and YD Mgaya, 2014. A comparison of diurnal dynamics of water quality parameters in Nile tilapia (Oreochromis niloticus, Linnaeus, 1758) monoculture and polyculture with African sharp tooth catfish (Clarias gariepinus, Burchell, 1822) in earthen ponds. Aquaculture Research, 6: 1-13.

17. Toufique, KA and B Belton, 2014. Is Aquaculture Pro-Poor? Empirical Evidence of Impacts on Fish Consumption in Bangladesh, World Development, 64: 609-620.

18. Turcios AE and J Papenbrock, 2014. Sustainable treatment of aquaculture effluents - what can we learn from the past for the future? Sustainability, 6: 836-856.

19. Tyson RV, DD Treadwell and EH Simonne, 2011. Opportunities and Challenges to Sustainability in Aquaponic Systems. HortTechnology, 21: 6-13.

20. Wilson $A L$ and VL Brian, 2006. A Comparison of Three Different Hydroponic Sub-systems (gravel bed, floating and nutrient film technique) in an Aquaponic Test System. Aquaculture International, 14: 539-550. 